\title{
Oil Palm Policy, Land Use Change and Community Livelihoods (OLCL) in Indonesia: A Sustainability Framework
}

\author{
Dennis Mark Onuigbo, Bonar Marulitua Sinaga, and Harianto
}

\begin{abstract}
The global demand for crude palm oil (CPO) has continuously increased with enormous economic benefits for governments and producers. To maximize the benefits, government policies have aimed at increasing CPO production usually through increasing the total harvested area (THA). However, increasing CPO production with the increase in THA results in both land use and livelihood changes. Modeling the complex relationship that exists between oil palm production and issues of land use and livelihoods changes holds the key to understanding their determinants and sustainability approach. At this stage, the conceptual framework was developed with targets of formulating evidence based policies with better economic, environmental and social outcomes using a 24years historic data with the simultaneous equations modeling technique.
\end{abstract}

Index Terms-Land use change, livelihoods, oil palm policy, sustainability.

\section{INTRODUCTION}

\section{A. Background}

Indonesia is the world's largest producer of palm oil [1]. Since world demand for palm oil is increasing with large revenue for producers and governments [2], policies have targeted a steady increase in its production. These policies according to [3] have made oil palm companies, its employees and core stakeholders better off while most community members and environment are made worse off.

Thus, increasing oil palm production with the current business as usual of increasing total harvested area (THA) will continue to incur higher environmental and social cost. The impact of oil palm production on the environment can be seen through land use change (LUC), while the social cost can be estimated through livelihood changes.

In the case of LUC, it can be defined by its cause. In line with the works of [3]-[6], LUC here was defined as the conversion of rainforest, other agricultural lands, soil biomass/ peatlands into oil palm plantation. On the other hand, Livelihood is the people's ability to access assets which include material and social resources required for daily living.

Thus, as policies are made to increase Oil palm production, it is important for such policies to consider LUC and the livelihood changes in the community. This is because the

Manuscript received October 25, 2016; revised June 1, 2017.

The authors are with Bogor Agricultural University, Indonesia (e-mail: simple14all@gmail.com). vulnerability of the community to trends, changes (e.g. Climate change), seasonality and shocks depends on the community access to five standard livelihood assets defined by DFID, FAO and CARE sustainable livelihood frameworks and these assets are influenced by LUC resulting from Oil palm production.

Globally, land area of mature oil palm increased from 3.5 million Hectare to 13.1 million hectare between 1975 to 2005 (about 9.6 million Ha within 30years) with Indonesia and Malaysia having over $85 \%$ of global CPO production [7].For Indonesia, Oil palm production is a major cause of land use change as it has been implicated for forest cover loss of 40 million ha (Mha) of land which amounts to about $30 \%$ reduction in forest land [4]. Most authors have also noted that Oil palm production caused loss of biodiversity, greenhouse gas (GHG) emission, forest fire, land disputes and human rights conflicts ([4], [8]) in Indonesia.

Even though reported as not been environmentally friendly with high social cost by several authors [3], [5], [6] and Non-governmental organisations [9], [10]. Oil palm production still have numerous socio-economic benefits and play a major role in poverty alleviation and income growth in rural oil palm communities in Indonesia [11]. Most studies on oil palm sustainability have used cross section data obtained through focus group discussions, site/household surveys and key informant interviews. However, the environmental cost and the changes in livelihood due to oil palm production is a subject that has not been modeled in time series due to its complex and data related issues.

This work is of the view that oil palm production can be more sustainable if its impact on environment and livelihoods can be historically and econometrically determined based on standard livelihood frameworks.

\section{B. Statement of Problem and Objectives}

Historically, the total forest area has continued to decrease while oil palm production (TOPP), total oil palm planted area (TPA) and degraded land area (DL) have increased across the years. This can be seen from the Table I below:

From Table I, the total oil palm planted area increased at an annual average of 346,030 ha, the total forest area which provides habitat for biodiversity and an important source of livelihood for the community decreased at an annual rate of 685,000ha.

Moreso, Oil palm production estate has grown tremendously over the years. This resulted in the competition for agricultural land between oil palm and other crops. It has been noted that the oil palm estate area has continued to gain over rubber and cocoa. The trend can be seen in Table II. 
TABLE I: TREND OF TOTAL OIL PALM PRODUCTION (TOPP) (1000MT), TOTAL ForEST AREA HA (TFA) AND DEGRADED LAND IN MHA (DL) IN INDONESIA FROM 2007-2013

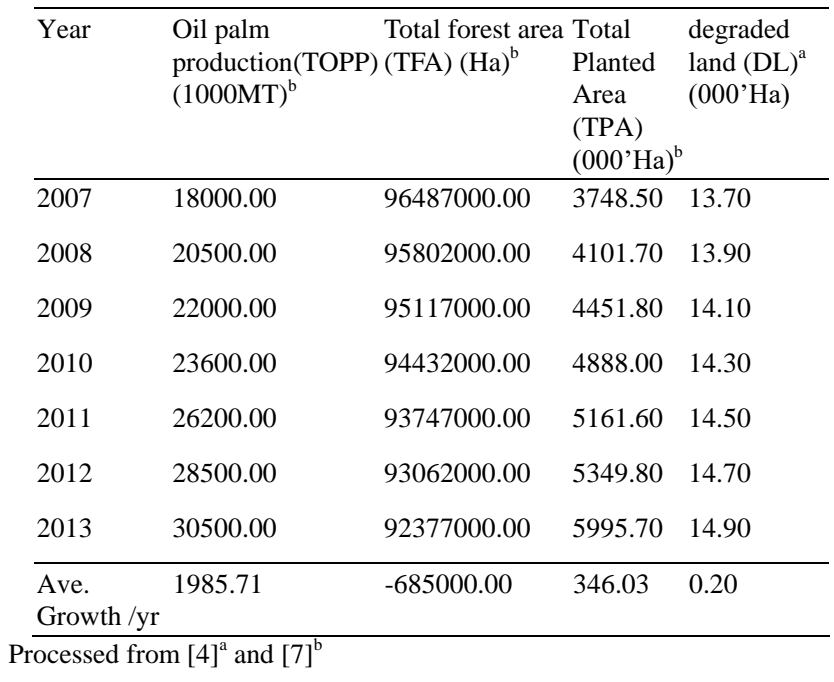

TABLE II: RUBBER, COCOA AND OIL PALM ESTATE AREA (000HA) IN INDONESIA FROM 1995-2015

\begin{tabular}{rrrr}
\multicolumn{4}{c}{ INDONESIA FROM 1995-2015 } \\
\hline Year & Rubber & Oil Palm & Cocoa \\
\hline 1995 & 471.9 & 992.4 & 125.4 \\
1996 & 538.3 & 1146.3 & 129.6 \\
1997 & 557.9 & 2109.1 & 146.3 \\
1998 & 549.0 & 2669.7 & 151.3 \\
1999 & 545.0 & 2860.8 & 154.6 \\
2000 & 549.0 & 2991.3 & 157.8 \\
2001 & 506.6 & 3152.4 & 158.6 \\
2002 & 492.9 & 3258.6 & 145.8 \\
2003 & 517.6 & 3429.2 & 145.7 \\
2004 & 514.4 & 3496.7 & 87.7 \\
2005 & 512.4 & 3593.4 & 85.9 \\
2006 & 513.2 & 3748.5 & 101.2 \\
2007 & 514.0 & 4101.7 & 106.5 \\
2008 & 515.8 & 4451.8 & 98.4 \\
2009 & 482.7 & 4888.0 & 95.3 \\
2010 & 496.7 & 5161.6 & 92.2 \\
2011 & 524.3 & 5349.8 & 94.3 \\
2012 & 519.2 & 5995.7 & 81.1 \\
2013 & 539.6 & 6170.7 & 84.7 \\
\hline
\end{tabular}

Processed from [12]

From Table II above, oil palm estate area has continued to increase over Cocoa and rubber. With the business as usual, it is expected that either the rubber and cocoa estate areas are converted to Oil palm estate or more natural rainforest areas will be converted. With this concern in 2010, the Norwegian government signed an agreement with the Indonesian government for a two (2) years moratorium on forest. The government agreed to invest $\$ 1$ billion in forest conservation projects in Indonesia to reduce greenhouse gas emission [2]. Two years later (in 2013) after the agreement, Oil palm estate increase by about 1,000,000 Ha as seen in Table II.

To provide sustainability approach, this work has targeted two broad questions which include: 1 . How might we know the actual determinants of increased oil palm production, Land Use Change and community livelihood?; and 2. how might we ensure sustainable oil palm production, land use and improvement in community livelihoods?

At this stage, we developed the conceptual framework that targets sustainability across economic, environmental and social lines. This conceptual framework will enable us as the work proceeds to: determine the factors that influence oil palm production, land use change and community livelihoods through econometric modeling and using a combination of sustainable livelihood frameworks; and to formulate policy alternatives that will ensure sustainable oil palm production, reduction in land use change and improvement in community livelihoods through policy simulation.

\section{Relevance of the Study}

This work tends to be among the rare if not the first attempt in the modeling and empirical determination of livelihood changes and land use change (LUC) due to human socio-economic behaviors.

It therefore would encourage innovative thoughts towards the modeling and empirical determination of livelihood changes and the socio-economic approach to LUC. This has been encouraged as a better way to understanding LUC, its drivers and implications as its fills the gap in the usual geophysical land use modeling using remote sensing and geographic Information System (GIS) [13].

The results of this study will add scientific knowledge to students, researchers, private and government institutions especially in areas of policy making, environmental sustainability, better livelihoods standards, agricultural development and trade.

It will make more specific and evidence based policy recommendations to the Indonesian government and indirectly to other oil palm producing countries on better approach towards sustaining economic benefits while minimizing both the environmental and social costs due to oil palm production.

It aligned with the three aspects of sustainable development represented in the sustainability triangle as it ensures better economic, social and environmental outcome.

\section{Limitations of the Study}

Data used were aggregated and Community members were not stratified.

\section{LITERATURE REVIEW}

\section{A. Related Literature}

Relating to the environmental and social impact of oil palm production, [3] writing extensively on the title "Environmental and Social Impacts of Oil Palm Plantations and their Implications for Biofuel Production in Indonesia" reported that oil palm production resulted in air, land and water pollution on the side of environment while its benefit were not properly distributed as traditional landowners' rights were not recognized; land disputes and increase in land prizes were relevant social impact. The study selected three plantation sites which include west papua (Manokwari), West Kalimantan (Kubu Raya), and Papua (Boven Digoel) recommended that the government should enforce land regulations and concessions, recognize traditional land rights, improve monitoring of labour practices and to restrict the use of forested land for plantation. This work differed from [3] because cross section data collected through household survey, focus group discussion (FGD) and key informant interviews were used and livelihood measurement was focused on the general notions of land rights and access, 
shares of returns from plantation activities.

In Word Agroforestry Centre's technical brief titled "Socio-Economic Impact Assessment of Palm oil production", [5] focused on the social and economic context in Oil palm production. They noted that about 12 or $9 \%$ of villages located about 10 or $20 \mathrm{~km}$ around an oil palm plantation make their major income from oil palm activities as smallholders or labour; thus, such villages have performed well on physical, financial and human capital as they show low level of malnutrition, higher income (2-3times within 5years for households), immigration and more males. However, land access and rights remained the major social cost of Oil palm production. A one way ANOVA test was used to analyse GPS data, village maps, data from BPS (2003) and PODES (extensive village database, 2008) for 23 oil palm estates. Livelihood was measured with household survey of 78villages based on physical, financial and human capital highlighted earlier.

In another study titled "Land-Use and Livelihoods - A Malaysian Oil Palm Scheme and its Social and Ecological Impacts", [6] researched the impact of the Sarawak Land Consolidation and Rehabilitation Authority (SALCRA) oil palm scheme on livelihood security and environmental sustainability in the Sarawak area of Malaysia. They noted that the SALCRA diversified household income while the environmental concerns included deforestation, biodiversity loss and majorly on soil quality loss. They used soil active carbon analysis and suggested the need for incentive for soil quality conservation and sound management practices for the environment to sustain livelihoods.

This work has taken a slightly different perspective by systematically viewing the impact of oil palm production on land use change and community livelihoods. It was based on sustainable livelihood standards developed by credible international organizations and the sustainability triangle in [14]. It employed standard econometric procedures using time series data which maybe better in showing changes over a period. From modeling and simulation, more specific policy recommendations are made.

\section{B. Historical Overview of the Indonesian Oil Palm Policies 1993-2006}

According to [8], the government policies on oil palm have passed through five (5) phases from the PIR- Trans phase of October, 1993 to the decentralization phase of 2002-2006.

The first stage the Perkebunan Inti Rakyat (PIR-Trans) phase was introduced in Octobre, 1993. This stage brought about the Translok and transmigrasi sisipan which brought about labour migration to oil palm plantation areas.

The second phase termed the Deregulation phase was operative from 1993 to 1996; here local governments were empowered to allow land up to $200 \mathrm{ha}$.

The privatization phase marked the third phase. This phase lasted from 1996 to 1998. In this stage ownership of oil palm plantation took a more organized approached as land use permission namely izin prinsip, izin tetap and izin perluasan were issued This aims to reduce issues of land disputes and ownership assurance.

The fourth stage was the Cooperatives Phase from 1998 to 2002. Here, concerns on having protected forest (hutan lindung) started, land custodies for the provincial government reached $1000 \mathrm{Ha}$ but higher about $20000 \mathrm{Ha}$ will pass through the Federal Ministry of Forest \& Estate crops.

The fifth stage was the decentralization Phase (2002-2006). Here, Local governments and districts can authorize with the consent of the legislature on Land Resources \& budget up to $1000 \mathrm{Ha}$. Concerns on use of degraded lands and the forest Moratorium was noted at this stage.

Basically, the trend involved an increase in land allocation for Oil Palm Estate.

\section{Oil Palm Policy Reflecting International Trade}

Gains from trade can be obtained in the form of either increasing productivity or consumption at low opportunity cost or ensuring welfare gains for the producer. As international trade restrictions were removed to gain from free trade, domestic prices and total CPO consumption increase as CPO demand (CPOD) becomes domestic consumption plus $\mathrm{CPO}$ export (CPOX).Three basic policy instruments which touched on oil palm production were used to stabilize the domestic economy and minimize welfare loss for the domestic consumers. They include: 1. Use of export tax (1994); 2. Use of buffer stock (Bulog subsidized import of olein); and 3. Directed sales (where $80 \%$ CPO from government owned plantations (PTPNs) are sold to domestic market at prices less than international market price) [15].

The windfall profit tax model was used. In this system, when CPO prices exceed USD 700/MT, the tax rate increases by $1.5 \%$ for each $\$ 50$ increase in the international CPO price upto USD 950/MT. However, it becomes $2.5 \%$ for each $\$ 50$ increase upto a ceiling of $25 \%$ for prices in excess of USD 1250/MT [16].

\section{The Policies and Land Use Change}

Considering Land use change, it must be noted that from the first stage to the fifth stage of the oil palm policy, land allocation for oil palm plantation increased drastically. Land custody at the Local government level alone rose from 200ha during the deregulation phase upto 1000ha. Even though regulations were developed along these phases to avoid unintended expansion and forest degradation, the regulations have not been followed with complete obedience as illegal land expansion for plantation are still possible without serious restrains.

More so, current government expansion targets land conversion of about 6 million hectares of land for biofuel production [16], [17].

\section{Concept of Sustainable Community Livelihoods}

Food and Agricultural Organisation (FAO), Cooperative for Assistance and Relief Everywhere (CARE), Oxford Committee for Famine Relief (OXFAM), United Nations Development Programme (UNDP) have all developed livelihood frameworks which are broadly similar.

Livelihood as earlier defined is the ability to access assets which include human, social, financial, natural and physical capital which are necessary for people's daily living. Livelihoods are sustainable when access to the assets above can be maintained without constituting harm to the 
environment and social wellbeing. The concept of livelihood and the assets are captured in the CARE, Murray \& Mary and FAO sustainable livelihood frameworks.

\section{A. The CARE Livelihood Framework}

According to CARE framework in [18], livelihood circles around the household's ability to use resources or services such as water, food, health, shelter and education. The mentioned resources are considered as basic needs for the households to build its social, physical, human and financial assets which serve as buffer for shocks and stresses.

The shock or stress may result from seasonality (dry or rainy seasons as in Indonesia) and uncertainties like famine, natural or man-made disasters. An example was the recent forest fire in places with high concentration of oil palm plantation in Indonesia like Jambi, Riau and Palembang Sumatra between September until November 2015 which left huge greenhouse gases on the atmosphere and made breathing difficult. According to CARE, the assets help to absorb the shocks and improve the access to the resources. However, barriers such as position in society/ status, culture, gender, religion etc restrict the household's access to the stated resources.

\section{B. Murray and Mary's Sustainable Livelihood Frameworks}

The livelihood framework developed in [19] was adapted from the DFID sustainable livelihood guidance sheet. It noted that the social assets included cooperation, networks, family support, friendships, relationships of trust/exchanges, Partnership and collaboration, interconnectedness and Political participation while Personal assets included motivation, self-esteem, self-confidence, self-perception, emotional well-being, assertiveness and spirituality. They explained the physical assets with child/elder care, secure shelter, clean affordable energy, information, banking and access to related services, basic consumer needs such as local grocery store and other services, tools and equipment, affordable transportation and natural resources.

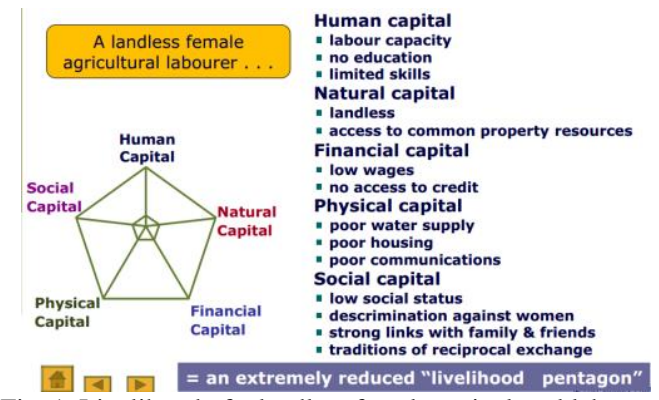

Fig. 1. Livelihood of a landless female agricultural labourer.

More so, Skills (including technical and interpersonal), knowledge, ability, employability and earning power, good health and leadership were noted as components of human assets while Income from productive activity, available finances/savings, remittance from government transfers, family credit rating and access to credit all make up the financial assets.

\section{Livelihood Framework for a Landless Female Agricultural Labourer}

On a more specific note, [20] described livelihood based on the five livelihood capital as shown in Fig. 1.

The framework in Fig. 1 was used to describe the factors that influence the livelihood of a landless female agricultural labourer. It generally showed a reduced livelihood.

\section{THE OLCL SUSTAINABILITY FRAMEWORK}

With its numerous economic benefits, Oil palm production was observed to have both environmental and social cost. The environmental cost was measured from its impact on land use change while the social cost was estimated from its impact on community livelihoods. To suggest a sustainability approach to oil palm production, this work identified relevant variables concerning Oil palm production, LUC and community livelihoods over time series of 24years. These variables were modeled using the simultaneous equation model where relevant test and re-specification were made to obtain the determinants or factors that increase or decrease oil palm production, LUC and community livelihood. Policy simulation procedure was then used to suggest best sustainability approach that increase Oil palm production with reduced LUC and better community livelihood. The operational conceptual framework is as shown in Fig. 2 below:

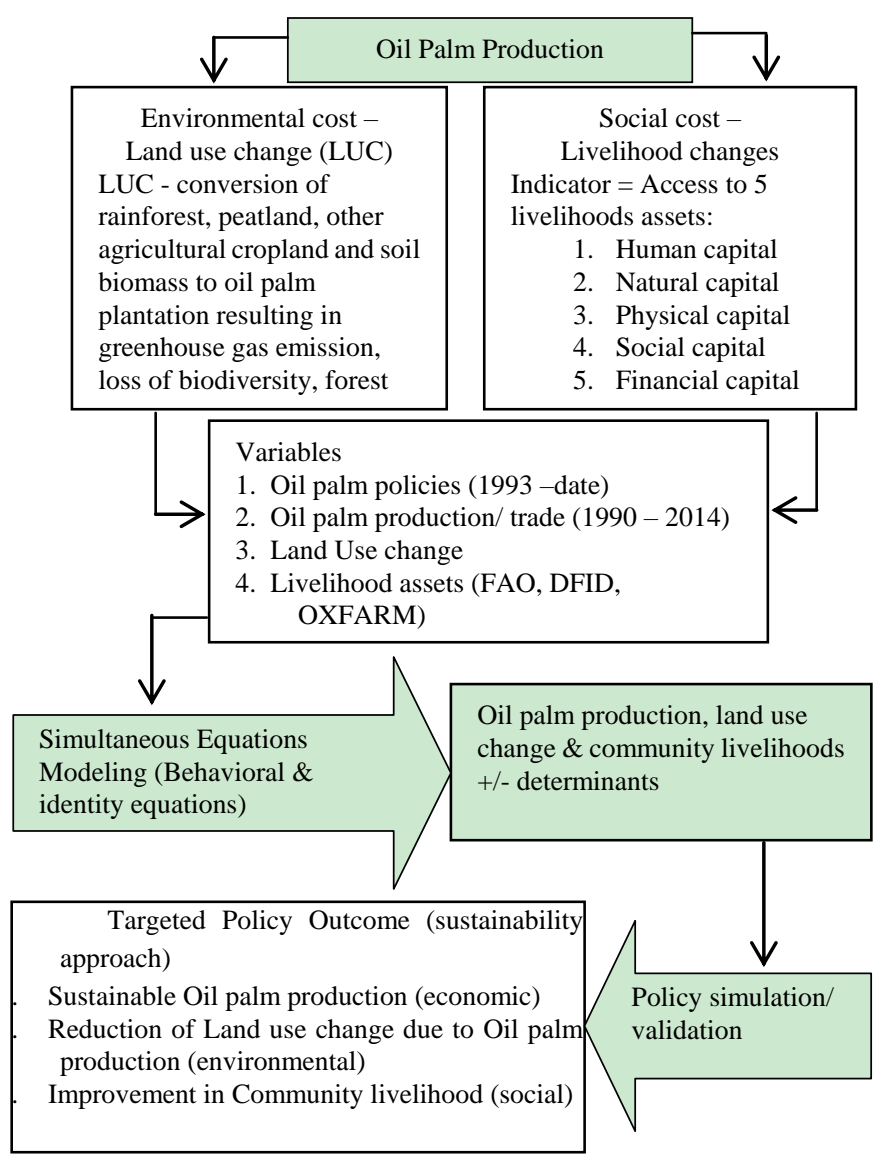

Fig. 2. The OLCL sustainability framework.

\section{DATA AND METHOD}

The research used time series data from 1990 - 2014. The data was obtained from FAO Statistics, Statistics Indonesian (Badan pusat statistik - BPS), WorldBank subnational data (Indonesia database for policy and economic research INDODAPOER), Indonesian National Disaster Management 
Authority (Badan Nasional Penanggulangan Bencana BNPB) and other relevant sources. The selected oil palm communities included Riau, Jambi, North and South Sumatra, Central, East and West Kalimantan. These provinces are recognized as top oil palm producing provinces in Indonesia.

As noted in Fig. 2, the simultaneous equations modeling technique was used and the Two Stage least square method of estimation was employed to curtail errors of misspecification or other stochastic bias. The modeling will pass through stages of model specification, model identification, model estimation, model evaluation and validation. Policy simulation is done for suggesting policy alternatives with better sustainability outcome.

\section{CONCLUSION}

Aside studying the oil palm policies, land use change and livelihoods. We also reviewed the activities of REDD+ and the Carbon trade Initiatives and saw that they have strong arguments and good potentials, however, the implementation and scaling up continues to have strong challenges ranging from issues of trust and the right political will from both developed and developing countries factions. Developing robust domestic policies that puts the general human good at the center of focus still stands a better and smoother path towards ensuring sustainable land use and improved livelihoods for indigenous people. Simultaneous modeling of the complex nature of oil palm production and its associated economic, social and environmental cost and benefits promises better and sustainable outcome for all stakeholders; community, producers and governments.

\section{ACKNOWLEDGMENT}

Dennis M. Onuigbo thanks his parents Mr/Mrs. Mark Onuigbo and family for their support. He thanks the Indonesian government for the Kemitraan Negera Berkembang (KNB) masters scholarship. He thanks his lecturers, supervisors Bonar M.S \& Harianto, staff of the Faculty of Economics \& Management and Pascasarjana IPB for their special care.

\section{REFERENCES}

[1] B. A. Wisena, A. Daryanto, B. Arifin, and R. Oktaviani, "Sustainable development strategy and the competitiveness of Indonesian palm oil industry," International Journal of Managerial Studies and Research (IJMSR) vol. 2, no. 10, pp. 102-115, 2014

[2] World Growth, "The economic benefit of palm oil to Indonesia," A report by World Growth, February, 2011.

[3] K. Obidzinski, R. Andriani, H. Komarudin, and A. Andrianto, "Environmental and social impacts of oil palm plantations and their implications for biofuel production in Indonesia," Ecology and Society, vol. 17 , no. 1, p. 25, 2012.

[4] B. Wicke, R. Sikkema, V. Dornburg, and A. Faaij, "Exploring land use changes and the role of palm oil production in Indonesia and Malaysia," Journal of Land Use Policy, vol. 28, pp. 193-206, 2011

[5] S. Budidarsono, S. Dewi, M. Sofiyuddin, and A. Rahmanulloh, "Socioeconomic Impact assessment of palm oil production," Technical Brief: Palm oil Series, Bogor, ID, no. 27, 2012.

[6] N. Wilms-Posen, M. Boomkens, S. d'Apollonia, A. Klarer, E. M. Kraus, and L. L. Tynell, "Land-use and livelihoods - A Malaysian oil palm scheme and its social and ecological impacts," The Journal of Transdisciplinary Environmental Studies, vol. 13, no. 2, 2014.
[7] FAOSTAT (Food and Agriculture Organization Statistics). (2015) Resource Statistics. [Online]. Available: http://faostat.fao.org/

[8] M. Colchester, N. Jiwan, Andiko, M. Sirait, A. Y. Firdaus, A. Surambo, and H. Pane, "Promised land: Palm oil and land acquisition in Indonesia - implications for local communities and indigenous peoples," Forest Peoples Programme, 2006.

[9] FOE (Friends of the Earth), "Greasy palms - palm oil, the environment and big business," Friends of Earth, London, UK, 2004.

[10] Greenpeace. (2015). Percaya APP Sinar Mars. [Online]. Available: http://youtube.com/Percaya_APP_Sinar_Mars_.mp4

[11] Goenardi, "Prospective on Indonesian palm oil production," presented at the International Food \& Agricultural Trade Policy Council's Spring Meeting, Bogor, ID, May 12, 2008.

[12] BPS (Badan Pusat Statistik). (2014). Agriculture. [Online]. Available: http://bps.go.id//

[13] H. Nagendra, D. K. Munroe, and J. Southworth, "From pattern to process: Landscape fragmentation and the analysis of land use/land cover change," Agriculture, Ecosystems and Environment, vol. 101, no. 2-3, pp. 111-115, 2004.

[14] M. Fritz and G. Schiefer, "Sustainability in food network," German Association of Agricultural Economics, Germany: University of Bonn, 2014.

[15] D. F. Larson, "Indonesia's palm oil subsector,” The World Bank Policy Research Working Paper Series 1654, 1996.

[16] D. Cervantes-Godoy and J. Dewbre, "Economic importance of agriculture for sustainable development and poverty reduction: Findings from a case study of Indonesia," Global Forum on Agriculture, November 29-30, 2010.

[17] M. Basri and A. Patunru, "Survey of recent developments," Bulletin of Indonesian Economic Studies, pp. 295-319, 2006.

[18] K Westley and V. Mikhalev, "The use of participatory methods for livelihood assessment in situations of political instability: A case study from Kosovo," Working Paper no. 190, 2002

[19] J. Murray and M. Ferguson, "Women in transition out of poverty: An asset-based approach to building sustainable livelihood," Women and Economic Development Consortium, January, 2001.

[20] FAO (Food and Agriculture Organization) Policy Learning, "Socio-economic and livelihood Analysis in investment planning," FAO Policy Learning, 2008.

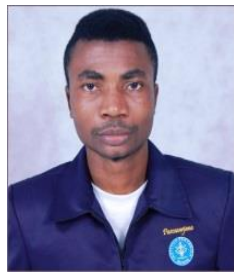

Onuigbo Dennis Mark was born in Yala Local Government Area of Cross River State, Nigeria on the $10^{\text {th }}$ of August, 1987. He is a graduate student with major in agricultural economics (MSc.) at Bogor Agricultural University, Indonesia.

His major research interests are on resource and environmental economics, agricultural trade and policies. He has worked on issues related to livelihoods and sustainability.

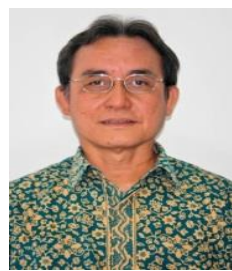

Bonar M. Sinaga was born in Medan, Sumatra province of Indonesia on the $30^{\text {th }}$ of November, 1948 $\mathrm{He}$ has a Doctoral degree at University of the Philippines, Los Banos, Philippine.

He is a professor in the department of Resource and Environmental Economics, Bogor Agricultural University, Indonesia. He was the former head of Agricultural Economics graduate program. His major research interests are on agricultural trade, resource and environmental economics.

Prof. Sinaga is currently working on the "Impact of Government Policy and External Factors on Trade, Farmers Welfare and Palm Oil Industry in Indonesia."

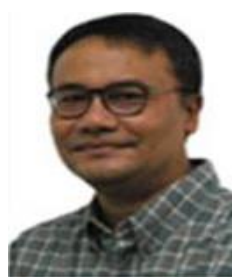

Harianto was born in Bali, Indonesia on the $21^{\text {st }}$ of October, 1958. He has a Doctoral degree at La Trobe University, Melbourne, Australia.

$\mathrm{He}$ is a senior lecturer in the Department of Agribusiness, Bogor Agricultural University, Indonesia. His major research interest is on agricultural economics and policy.

Dr. Harianto was the personal adviser to the president Republic of Indonesia (2010-2014). He is currently working on "The Impact of Palm Oil Industry on Regional Socio-Economic Development” with Dr. Amzul Rifin. 